\title{
Banking Sector Performance During the COVID-19 Crisis in the Republic of North Macedonia
}

\author{
Vesna Georieva Svrtinov, ${ }^{1}$ \\ Emilija Miteva-Kacarski, ${ }^{2}$ \\ Vlatko Paceskoski, ${ }^{3}$
}

UDC 336.71:005.332.1]:303.724\}:616.98:578.834(497.7)

${ }^{1}$ University Goce Delcev Stip, Faculty of Economics, vesna.svrtinov@ugd.edu.mk
2University Goce Delcev Stip, Faculty of Economics, emilija.miteva@ugd.edu.mk
${ }^{3}$ University Goce Delcev Stip, Faculty of Economics, vlatko.paceskoski@ugd.edu.mk

Abstract

This paper explores the effect of the COVID-19 crisis on commercial banks in the Republic of North Macedonia. It has used data from financial statements of the banks in order to find out if there are changes in banks profitability, as well as banks exposure on liquidity and credit risk in the period of Corona crises and before the crises. Furthermore, we explore if there are changes in the credit and deposit potential of banks and whether there are an increase in non-performing loans. We conclude that even the banking sector has faced several challenges, it maintained its stability and contributed to mitigation of the consequences of the corona crisis. This, on the one hand, is a result of public confidence in the banking system, but, on the other hand is due to the rapid reaction of the National Bank of Republic of North Macedonia. In 2020, the banking system made a higher profit compared to the previous year. Net interest income was the most significant in the structure of total income and did not decrease in 2020 compared to 2019. Banks ensured solid growth of loans and deposits as well as properly managed their credit and liquidity risk. It is important to emphasize that banks have maintained a stable and solid liquidity position, which is one of the main pillars of the stability of the banking system, especially important in times of crisis. There was also no increase in credit risk, on the contrary there was a decrease in the percentage of non-performing loans. This is primarily due to regulatory measures taken by the National Bank in the field of credit risk management and the introduction of the possibility of temporary deferral of loans.

Key words: bank profitability, banking system in the Republic of North Macedonia, COVID-19 pandemic, credit risk, liquidity risk, non-performing loans

\section{Introduction}

The coronavirus pandemic has reached almost every country in the world. Many people have lost their jobs or seen their incomes cut. Unemployment rates have increased across major 
economies. Many countries are experiencing a recession. Because of globalisation, international demand for goods due to the widespread recession declined, which have had negative impact on international trade.

Republic of North Macedonia is also not immune to the consequences caused by the corona crisis. The economy of North Macedonia declined by almost $5.5 \%$ in 2020 . The trade deficit was $-16.7 \%$ of GDP. The industrial production index fell by $10.6 \%$ on average in comparison with previous year. Employment rate declined, but only for $1.8 \%$, mainly due to government support measures [1].

In this paper we examine the influence of Covid 19 crisis on banking sector performance in our country.

On December 31, 2020, in the Republic of North Macedonia existed 16 depository institutions, out of which 14 banks and two savings houses. Compared to the previous year, the number of banks decreased by one, while the number of savings houses remained the same.

Despite the pandemic, the banks in 2020 achieved a positive financial result, i.e. all banks ended the year with a profit. It can be shown on the graph below.

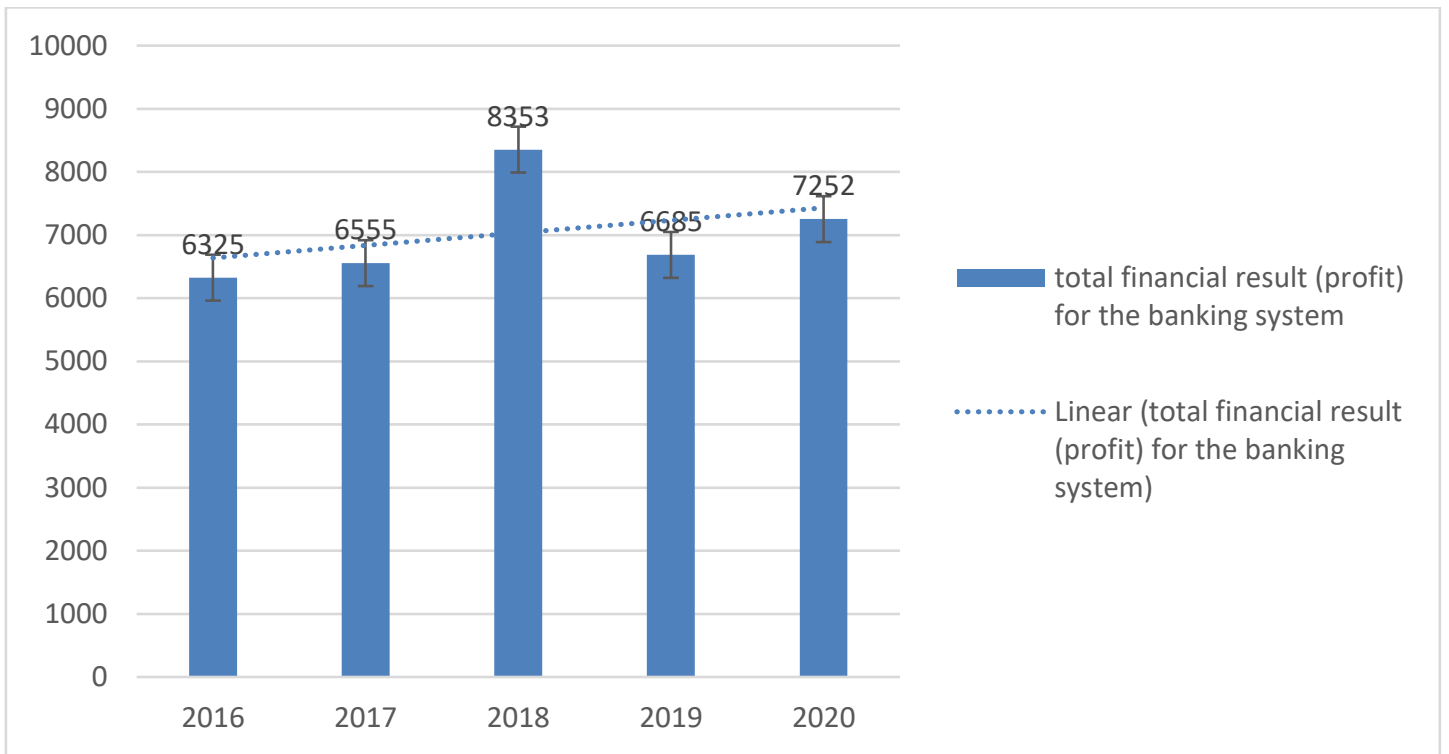

Graph 1: Total profit of banks in millions of denars (December 2016- December 2020)

Source: Data are taken from NBRNM [2]

As we can see from the chart, the linear line shows an upward trend and the biggest profit during this period was realized in 2018. In December 2020, total profit was higher in comparison with 2019 for $8.48 \%$.

Market risk indicators were satisfactory and controlled. Credit risk decreased in 2020, which is reflected in the lower level of non-performing loans. The dynamics of non-performing loans were influenced by the regulatory measures taken by the National Bank in the field of credit risk management, above all, the introduction of the possibility of temporary deferral of loans due to the Corona crisis. This measure contributed to the temporary postponement of the eventual realization of the credit risk in the banks' portfolios. On the graph below we presented the non-performing loans as a share of total loans in specified months in the years: 2018, 2019 and 2020. 


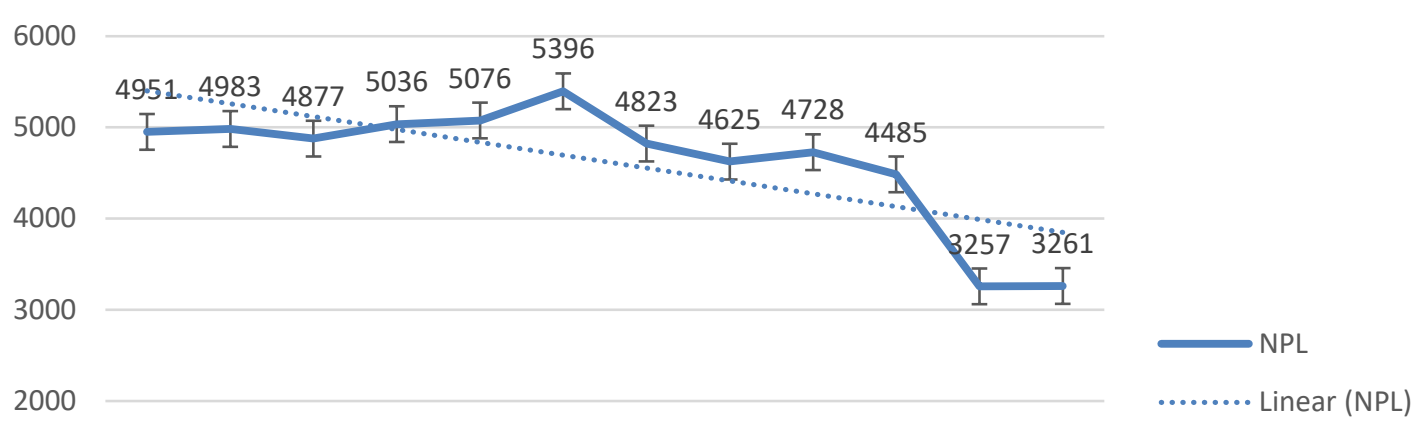

1000

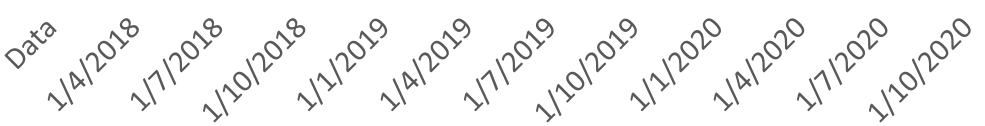

Graph 2. Non- performing loans as a share of total loans

Source: Author calculation based on data CEIC[3]

From the graph above we can see significant reduction of non-performing loans in 2020 , due to the measures mentioned before. For instance, non-performing loans in October 2020 were lower by $29.49 \%$ and $33.13 \%$ compared to the same months in 2019 and 2018 respectively. In 2020, Macedonian banks maintained a stable and solid liquidity position, which is one of the main pillars of the stability of the banking system, especially important in times of crisis [4].

The reminder of this paper is structured as follows. Following this introduction, section 2 present literature review, section 3 presents data and methodology. In section 4 we present the results and discussions of the regression model, and the final section concludes the study.

\section{Literature review}

Since the beginning of the Covid 19 virus crisis, many economists, sociologists and other analysts and researchers have been analyzing the effects it can have on countries around the world. Recently, there have appeared number of empirical studies that analyze how the crisis affects the economic performance of countries affected by the crisis.

Some of them are focused on the impact that pandemic has on the performance of the banking sector. It is well known that the banking sector has the role of supporting firms and households during this period of lower revenues and incomes, which has triggered important policy actions by financial supervisors and governments.

According to Beck, Miles and Wilson [5] the crisis negatively affected profits and bank capital, due to several factors. First of all, firms that have stopped working miss out on revenues, and therefore might not be able to repay loans. Similarly, households with members who have lost their jobs or have less income, might not be able to repay their loans. Second, banks are negatively affected as bonds and other traded financial instruments have lost their value, resulting in further losses for banks. Furthermore, banks face lower non-interest revenues, as there is lower demand for their different services.

A study made by World Bank Group [6] which include bank data such as stock prices, balance sheets, and ownership, for 53 countries and 896 commercial banks, found out that within the financial sector, banks are expected to face greater losses than other financial institutions. The results of the study suggest that the adverse impact of the COVID-19 shock on banks was 
much more pronounced and long-lasting than on the corporates, as well as other non-bank financial institutions, revealing the expectation that banks are to absorb at least part of the shock to the corporate sector. Furthermore, larger banks, public banks, and to some extent better capitalized banks suffered greater reductions in their stock returns, reflecting their greater anticipated role in dealing with the crisis.

Another study analyses Bangladesh banking sector as a case study of an emerging economy and examines the possible impacts of the pandemic on the country's banking sector, which already has a high level of NPLs and many systemic problems. Findings suggest that all banks are likely to see a fall in their risk-weighted asset values, capital adequacy ratios, and interest incomes [7].

In China the most affected was smaller regional banks that service small and medium enterprises (SMEs). Generally, SMEs struggle to obtain financing despite their major role in employment and job creation. Study made by Haasbroek [8] found out that smaller banks are particularly exposed to economic shocks, because they have weaker risk management and lower capital buffers.

The European Central Bank analyzed the impact of the pandemic on more than 2,000 small and medium-sized banks in Europe. Overall, these banks entered the pandemic crisis with relatively few bad loans on average, ample liquidity buffers and a good solvency position. In terms of asset quality, the banks most affected by the crisis are those with a significant concentration of exposures to economic sectors that have been severely hit by the pandemic. These include the hospitality, retail trade and transport sectors, as well as some manufacturing subsectors. They conclude that, some banks are more vulnerable than others to the fallout from the COVID-19 crisis. This is due to a weaker solvency position or individual business model characteristics [9].

Furthermore, study made for European banks confirmed that this crisis is a bigger threat to banks than the eurozone debt crisis. The risk of the crisis spilling over into the banking systems of various EU countries is also high [10].

The purpose of this study is to see if there are changes in the banking sector of the Republic of North Macedonia in relation to banks profitability, due to decrease in interest income, commission income, furthermore whether there are changes in loans and deposits base, as well as increase in credit and liquidity risk in 2020 compared to 2019.

\section{Data And Methodology}

The sample for the present study included ten out of fourteen commercial banks in the Republic of North Macedonia. The datas for five of them: NLB Banka AD Skopje, Komercijalna Banka AD Skopje, Ohridska Banka AD Skopje, TTK Banka AD Skopje, Shparkase Banka Macedonia $A D$ Skopje, are taken from web site of Electronic reporting system from listed companies on Macedonian stock exchange [11], while the datas for Stopanska Banka AD Skopje, Stopanska Banka AD Bitola, Capital Banka AD Skopje, Univerzalna Investiciona Banka AD Skopje and Centralna Kooperativna Banka Ad Skopje, are taken from the official web pages of the banks. For other banks until the period when the survey was conducted there was no data available for 2020 year.

As a dependent variable we use bank profitability, measured as a Profit (loss) for the financial year.

The independent variables in this study are: interest income, fees and commission income which are based on the prior literature, where the most cited variables that have an effect on banks profitability. Furthermore, we analyze the impact of credit and deposit base on bank profitability as well as total capital and reserves. The data for these variables are taken from the banks balance sheets and banks income statements. In order to make comparison we examine two years, 2019 before Corona crisis and 2020 during the crisis.

Below we present the descriptive statistics of the variables of interests. 
Table 1. Descriptive statistics for the variables in 2019 and 2020 year

\begin{tabular}{|c|c|c|c|c|}
\hline & & & & \\
\hline & Mean & Std. Dev. & Mean & Std. Dev. \\
\hline $\begin{array}{l}\text { Profit (loss) } \\
\text { for the } \\
\text { financial } \\
\text { year }\end{array}$ & 710423.3 & 957377.8 & 591406.1 & 795397.3 \\
\hline $\begin{array}{c}\text { Interest } \\
\text { income } \\
\text { (expense) } \\
\text { net }\end{array}$ & 1254765 & 1282211 & 1252008 & 1304642 \\
\hline $\begin{array}{c}\text { Fees and } \\
\text { commissions } \\
\text { income } \\
\text { (expenses) } \\
\text { net }\end{array}$ & 375705.7 & 383055.7 & 367586.9 & 360367.9 \\
\hline $\begin{array}{l}\text { Loans to } \\
\text { other clients }\end{array}$ & 25478913 & 23900303 & 26644163 & 24982584 \\
\hline $\begin{array}{l}\text { Deposits } \\
\text { from other } \\
\text { clients }\end{array}$ & 35506571 & 37524059 & 37647452 & 40831586 \\
\hline $\begin{array}{c}\text { Total capital } \\
\text { and } \\
\text { reserves }\end{array}$ & 5532977 & 5862639 & 6129029 & 6509676 \\
\hline
\end{tabular}

The values of the descriptive statistics in Table 1 in relation to the values of the standard deviation in all variables, suggest the high volatility of the data in the whole sample and in all the variables included in the model. According to the results, it indicates the different size of the banks involved in the analyses, and thus the different credit, deposit base, bank capital, as well as income based on interest and commissions. The basic business model of Macedonian banks, more precisely deposit collection and approval loans, did not notice significant changes in 2020.

The structure of total revenues of banks corresponds to the application of the traditional business model. Thus, net interest income is the most significant in the structure of total income and did not decrease in 2020 compared to 2019. It was similar with the commission income, which also did not decrease compared to last year, although it participate in a much smaller part of the banks income as opposed to interest income.

\section{Regression Model and discussion of the estimated results}

The model equation of the specified models subject to this research has the following form: 
Yit $=\beta 0+\beta 1{ }^{*} X 1$ it $+\beta 2 * X 2 i t+\beta 3{ }^{*} X 3 i t+\beta 4{ }^{*} X 4 i t+\beta 5 * X 5 i t+\varepsilon t$

Where:

Yit, represents the bank profitability represented by Profit (loss) for the financial year.

The independent variables $\mathrm{X} 1-5$ are represented by: Interest income (expense) net for $\mathrm{x} 1$; Fees and commissions income (expenses) net for $\mathrm{x} 2$; Loans to other clients for $\mathrm{x} 3$; Deposits from other clients for $x 4$ and Total capital and reserves for $x 5$. The influence of the dependent form on the independent variables should be determined from the coefficients $\beta 1-5$.

Before displaying the data in a model, we test them for their heteroskedasticity, normality, and if they have proper model structure using Ramsey reset test.

\begin{tabular}{|c|c|c|}
\hline Tests & $\mathbf{2 0 1 9}$ & $\mathbf{2 0 2 0}$ \\
\hline Heteroskedasticity & 3.663144 & 5.051134 \\
Obs*R-squared & $(0.5989)$ & $(0.4097)$ \\
(Prob. Chi-Square) & & \\
\hline & & 0.551087 \\
Normality Test & 0.173458 & $(0.759160)$ \\
Jarque-Bera & $(0.916926)$ & 2.492376 \\
Ramsey RESET Test & 1.392143 & $(0.2125)$ \\
\hline
\end{tabular}

We may conclude that the assumption for constant variance of the random error is not violated, in fact it is not related to the independent variables. Furthermore, the residuals are normally distributed and the model is well specified, i.e. has the correct proper functional form and corresponding variables.

After these tests we can continue with inferential statistics.

In order to see the relationships between dependent variable and independent variables in our model for 2019 and 2020 years, and the nature of those relationships, as well as their statistical significance, we have made a regression model, and the results are presented on the table below.

Table 2. Dependent and independent variables included in the model

\begin{tabular}{|c|c|c|}
\hline & Year 2019 & Year 2020 \\
\hline $\mathrm{X} 1$ & $\begin{array}{l}0.830024 \\
(0.0643)^{*}\end{array}$ & $\begin{array}{c}0.804896 \\
(0.1177)\end{array}$ \\
\hline $\mathrm{X} 2$ & $\begin{array}{c}0.175193 \\
(0.6425)\end{array}$ & $\begin{array}{c}1.483182 \\
(0.0496)^{\star *}\end{array}$ \\
\hline $\mathrm{X} 3$ & $\begin{array}{c}0.045247 \\
(0.0069)^{* * *}\end{array}$ & $\begin{array}{l}0.059064 \\
(0.0163)^{\star *}\end{array}$ \\
\hline $\mathrm{X} 4$ & $\begin{array}{c}-0.000810 \\
(0.9028)\end{array}$ & $\begin{array}{c}-0.021434 \\
(0.0195)^{\star *}\end{array}$ \\
\hline $\mathrm{X} 5$ & $\begin{array}{c}0.158549 \\
(0.1463)\end{array}$ & $\begin{array}{c}0.108347 \\
(0.3832)\end{array}$ \\
\hline R-squared & 0.998185 & 0.991442 \\
\hline Adjusted R -squared & 0.995916 & 0.980745 \\
\hline F-statistic & 439.9670 & 92.68376 \\
\hline
\end{tabular}




\begin{tabular}{|c|c|c|}
\hline & $(0.000014)^{\star \star *}$ & $(0.000318)^{\star \star *}$ \\
\hline Akaike info criterion & 25.16476 & 26.34478 \\
\hline Schwarz criterion & 25.34631 & 26.52633 \\
\hline
\end{tabular}

*significance at $10 \%$

** significance at $5 \%$

${ }^{* * *}$ significance at $1 \%$

According to the results presented in Table 2, in 2019 the variable Interest income (expense) net, affects the dependent variable with a significance level of $10 \%$. The coefficient indicator has a positive sign, which indicates a direct proportional relationship and causality with the profitability of the banking sector. This indicates that the increased revenues that banks generate through interest income inflows increase the profitability of banks, which is also a logical connection. The same independent variable in 2020 is also positive, but we didn't find statistical significance.

Independent variable: Fees and commissions income (expenses) in 2019 has a positive sign that again represents a logical link - an increase in fees and commissions income will increase the profitability of banks, but it is statistically insignificant. During 2020 , this variable again has a positive sign, but is statistically significant at the level of $5 \%$, which indicates that the profitability of banks depended on inflows based on fees and commissions.

The variable Loans to other client (these are loans to legal entities and individuals, excluding loans granted by banks to other banks) in both years are statistically significant by $1 \%$ and $5 \%$ for 2019 and 2020 respectively, and positive related with banks profitability.

The variable of Deposits from other clients (referring to deposits from legal entities and individuals with the exception of deposits from other banks) in 2019 is statistically insignificant and with a negative sign, but in 2020 it had a statistical significance of $5 \%$ and also was inversely related to the profitability of banks represented by Profit (loss) for the financial year. This can be interpreted that the payment of deposit interest on deposits, and in conditions of insufficient collection of interest on loans can reduce bank profitability.

The last independent variable we used in the research Total capital and reserves, has a positive sign, but is statistically insignificant in both years, and we cannot give an interpretation of the impact of this indicator on the profitability of banks.

We assume that some of these deviations from the theory are due to the fact that some of the banks did not have audited financial statements for 2020 , and four banks did not publish reports for this year at all.

Furthermore, according to the criterion Akaike and Schwartz, which assesses the quality of the model, we can conclude that the data for 2019 better reflect the model. We will mention again that this is due to some unaudited financial statements of the banks from which the data for 2020 are taken.

In addition, we will examine the magnitude of the association, or correlation, as well as the direction of the relationship between the dependent variable and each independent variable separately for the year before and during the Corona crisis using Pearson's correlation coefficient. 
Table 3. Correlation between dependent and independent variables for 2019 and 2020

\begin{tabular}{|l|c|c|c|}
\hline $\begin{array}{c}\text { Profit (loss) for } \\
\text { the financial } \\
\text { year }\end{array}$ & 2019 & 2020 \\
\hline & $\begin{array}{c}\text { Interest } \\
\text { income } \\
\text { (expense) net }\end{array}$ & 0.984833 & 0.925145 \\
\hline & $\begin{array}{c}\text { Fees and } \\
\text { commissions } \\
\text { income } \\
\text { (expenses) } \\
\text { net }\end{array}$ & 0.959398 & 0.919864 \\
\hline & $\begin{array}{c}\text { Loans to other } \\
\text { clients }\end{array}$ & 0.969359 & 0.906511 \\
\hline & $\begin{array}{c}\text { Deposits from } \\
\text { other clients }\end{array}$ & 0.939116 & 0.960586 \\
\hline & $\begin{array}{c}\text { Total capital } \\
\text { and reserves }\end{array}$ & 0.989706 & 0.949688 \\
\hline
\end{tabular}

As can be seen from the coefficients shown in the table above, all are positive, i.e. directly proportionally related and show a strong correlation between the variables (all coefficients are above 0.80 ). This means that bank profitability is strong positive correlated with all independent variables that we have used and that they move in the same direction.

The table below specifically examines the correlation between credit risk and liquidity risk and bank profitability measured by Profit (loss) for the financial year, because those banks that do not have audited financial statements have not submitted data on the level of credit and liquidity risk, so the data differ from the number of data used above.

Table 4. Correlation between dependent variable with credit and liquidity risks

\begin{tabular}{|l|c|c|c|}
\hline $\begin{array}{c}\text { Profit (loss) for the } \\
\text { financial year }\end{array}$ & 2019 & $\mathbf{2 0 2 0}$ \\
\hline & Credit risks & 0.951508986 & 0.95734668 \\
\hline & Liquidity risks & 0.822804851 & 0.571089409 \\
\hline
\end{tabular}

The data from the table shows very strong positive correlation between credit risk and liquidity risk and bank profitability except the correlation between liquidity risk and bank profitability in 2020 which is also positive but moderate.

In this context it's important to emphasize that with the regulatory changes from March, April and May 2020, the banks started to relief the credit burden of borrowers, mainly through the 
approval of a grace period, usually lasting up to six months, a period when the negative effects of the Corona crisis on the corporate sector and households were expected to be more pronounced (the relief covered about $40 \%$ of the loan portfolio). Due to the extended duration of the virus pandemic, in September 2020 banks made a second change in the contractual terms of loans, but this time more targeted, only for those categories of customers who are most affected by the crisis (persons who have lost their job, have a significant reduction in income, or have faced with increased treatment costs).

However, loans with an approved grace period, especially those with an approved second grace period, pose potential source of new ones non-performing loans, due to uncertainty whether after the end of the grace period these clients will be able to make regular repayment of loans. Possible credit losses from these loans will be realized during this year [4].

Macedonian banks maintained a stable and solid liquidity position. Main driver of the annual growth of liquid assets was the increased placements of banks in domestic long - term government securities (placements in Denar government bonds and in the Macedonian Eurobonds) and higher available deposits with the National Bank [4].

\section{Conclusion}

The Coronavirus pandemic has reached almost every country in the world. Republic of North Macedonia is also not immune to the consequences caused by the crisis.

In this paper we examine the influence of Covid 19 crisis on banking sector performance in our country. We used data from financial statements of the banks in order to find out if there are changes in banks profitability, as well as banks exposure on liquidity and credit risk in the period of Corona crises and before the crises.

Despite the pandemic, the banks in 2020 achieved a positive financial result, i.e. all banks ended the year with a profit.

Our research show that the variable interest income (expense) net in 2019 and in 2020 has direct proportional relationship and causality with the profitability. However, this finding is not statistically significant in 2020. Likeness, fees and commissions income (expenses) also have positive significant relation with bank profitability in both years. This confirms that bank profitability is heavily influenced by interest and commission income.

Deposits in both years are inversely related to the profitability of banks represented by Profit (loss) for the financial year. This can be interpreted that the payment of interest on deposits, and in conditions of insufficient collection of interest on loans can reduce bank profitability.

To examine the correlation, as well as the direction of the relationship between the dependent variable and each independent variable separately for the year before and during the Corona crisis we use Pearson's correlation coefficient. It shows very strong and positive correlation between bank profitability and all other variables in 2019 and 2020, except moderate correlation between bank profitability and liquidity risks during 2020 .

\section{References}

1. Organisation for Economic Co-operation and Development (OCED). The Covid-19 crisis in North Macedonia, tackling coronavirus (COVID-19) Contributing to a global effort, January, 2021.

2. National Bank of Republic of North Macedonia (NBRNM). Годишен извештај за 2020 година Скопје, април 2021 година..

3. https://www.ceicdata.com/en/indicator/macedonia/non-performing-loans-ratio.

4. National Bank of Republic of North Macedonia (NBRNM). Извештај за ризиците во банкарскиот систем на Република Северна Македонија во 2020 година, април 2021 година

5. Beck T, Miles D and Wilson, J. How is coronavirus affecting the banking sector? Economic Observatory, August, 2020,https://www.economicsobservatory.com/how-coronavirus-affecting- 
banking-sector.

6. Demirguc-Kunt A, Pedraza A and Ruiz-Ortega C. Banking Sector Performance During the COVID-19 Crisis, World bank Group, Policy Research Working Paper 9363, August, 2020 https://openknowledge.worldbank.org/bitstream/handle/10986/34369/Banking-Sector-

Performance-During-the-COVID-19-Crisis. pdf?sequence=1\&isAllowed $=\mathrm{y}$.

7. Barua B. and Barua S. COVID-19 implications for banks: Evidence from an emerging economy, SN Business \& Economics volume 1, Article number: 19,2021 https://link.springer.com/article/10.1007/s43546-020-00013-w.

8. Haasbroek M. Coronavirus crisis impacts China's credit system, Merics, Mercator Institute for China Studies, July 2020.

9. European Central Bank (ECB). Covid-19: The Impact On Europe's Smaller Banks Supervision Newsletter, November

2020 , https://www.bankingsupervision.europa.eu/press/publications/newsletter/2020/html/ssm.nl201 118_1.en.html.

10. DW. Coronavirus: Europe's banks struggle to survive a second wave retrieved by https://www.dw.com/en/coronavirus-europes-banks-struggle-to-survive-a-second-wave/a55269838.

11. https://www.seinet.com.mk/ShowLayoutDocs.aspx?Layout=DOC_12304. 